\title{
Método, ideologia e Estado: aproximações a partir do legado de Marx
}

\author{
Davi Machado Perez \\ Universidade Federal do Tocantins, Curso de Serviço Social, \\ Miracema, TO, Brasil (UFT)
}

\section{Método, ideologia e Estado: aproximações a partir do legado de Marx}

Resumo: Este ensaio, fruto de pesquisa bibliográfica, traz aproximações em torno da concepção marxiana de método, ideologia e Estado, objetivando contrapor-se à ideia da existência de um determinismo econômico na obra de Karl Marx. Posteriormente é feito um diálogo com autores marxistas atuais acerca do Estado na era do capitalismo monopolista, reafirmando o legado de Marx como ponto de partida fundamental para o desenvolvimento dos estudos sobre o Estado moderno e contemporâneo.

Palavras-chave: Método. Ideologia. Estado. Marxismo. Contemporaneidade.

\section{Method Ideology and State: Approximations based on Marx's legacy}

Abstract: This essay is the fruit of bibliographic research and offers reflections about the Marxist concepts of method, ideology and state, to question the idea that there is an economic determinism in the work of Karl Marx. It then dialogs with current Marxist authors who address the state in the era of monopoly capitalism, reaffirming Marx's legacy as an essential starting point for the development of studies about the modern and contemporary state.

Keywords: Methods. Ideology. State. Marxism. Contemporary.

Recebido em 17.05.2017. Aprovado em 05.09.2017. Revisado em 07.11.2017.

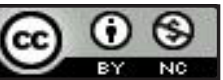

(C) O(s) Autor(es). 2018 Acesso Aberto Esta obra está licenciada sob os termos da Licença Creative Commons Atribuição-NãoComercial 4.0 Internacional (https://creativecommons.org/licenses/bync/4.0/deed.pt_BR), que permite copiar, distribuir e reproduzir em qualquer meio, bem como adaptar, transformar e criar a partir deste material, desde que para fins não comerciais, e que você forneça o devido crédito aos autores e a fonte, insira um link para a Licença Creative Commons e indique se mudanças foram feitas. 


\section{Introdução}

O presente ensaio bibliográfico se propõe a trazer algumas aproximações teóricas com a concepção de método, ideologia e Estado desenvolvida nas obras de Karl Marx, além de apontamentos sobre o Estado na era contemporânea do capitalismo monopolista. Buscamos problematizar algumas visões recorrentes que sustentam a existência de um suposto determinismo na análise econômica e também na concepção de Estado marxiana ${ }^{1}$. Para isso, reafirmamos o método dialético materialista enquanto pressuposto de todo o desenvolvimento teórico de Marx, trazendo algumas características da gênese e desenvolvimento do seu pensamento que nos permitem maior generosidade no contato com a complexidade da sua contribuição.

Partimos principalmente de obras em que Marx expressa claramente sua concepção de Estado: a Crítica da filosofia do direito de Hegel e o seu Prefácio à contribuição à crítica da economia política. Neste segundo, o autor apresenta um resultado geral dos seus estudos que é ponto de partida para o desenvolvimento da sua obra, sintetizando seu método e seu entendimento de categorias como: ideologia, estrutura, superestrutura, Estado. A partir daí, dialogamos com outras obras de Marx que trazem importantes elementos do seu método.

Para reafirmar posições que consideramos já presentes, mais ou menos desenvolvidas na obra de Marx, nos referenciamos em autores marxistas como Antonio Gramsci, Gyorgy Lukács e István Mészáros. Posteriormente é feito um diálogo com diferentes autores marxistas atuais, a maioria deles do Serviço Social brasileiro, sobre o Estado na era contemporânea do capitalismo monopolista. Trazendo, na conclusão, breves apontamentos sobre a possibilidade de superação da ordem socioeconômica vigente.

Não pretendemos aqui considerar que a obra marxiana por si só basta para uma análise consequente do Estado contemporâneo. Muitos fenômenos atuais necessitam de novas elaborações, e os limites temporais da obra de Marx não deram conta de nos trazer uma contribuição mais densa e profunda com foco nessa categoria. Nossa pretensão é evidenciar a sua concepção e o seu pressuposto de método, verificando sua validade para o desenvolvimento do estudo acerca do Estado moderno e contemporâneo. Para isso, dialogamos com alguns clássicos do marxismo no século XX e com autores que tratam da historicidade e atualidade do tema.

\section{Método, ideologia e Estado a partir de Marx}

Em sua Introdução à Contribuição para a Crítica da Economia Política, Karl Marx (2008, p. 268) apresenta a divisão dos seus estudos críticos da economia política e coloca em terceiro lugar a "sociedade burguesa compreendida sob a forma de Estado. O Estado em si". Como é sabido, ele não viveu o suficiente para aprofundar e elaborar a exposição dos elementos posteriores aos assinalados nos dois primeiros tópicos. No entanto, quando nos deparamos com esse plano de estudos e com a amplitude da obra que Marx se propôs a realizar, fica evidente que não podemos erigir em dogma ou resumir a pretensão da sua contribuição somente aos elementos aprofundados nos volumes de $O$ Capital. Esse tipo de simplificação é recorrente, de acordo com Netto (2011a), tanto entre os seus detratores quanto entre os seus seguidores, e acreditamos que podemos encontrar pistas importantes acerca do Estado se nos apropriamos do conjunto da obra marxiana.

Consideramos basilar o fato de que a dialética hegeliana sempre teve um peso determinante na concepção metodológica de Marx, e isso permaneceu ao longo de toda a sua obra. Evidente que sua dialética materialista possuía características diferentes da dialética de $\mathrm{Hegel}^{2}$, mas também preservava muitas semelhanças. $\mathrm{O}$ método marxiano não pode ser compreendido sem categorias centrais como: totalidade, mediação e contradição. Também não podemos considerar que as categorias que explicam complexos universais excluem as determinações no âmbito da singularidade e da particularidade.

Por isso, o conhecimento concreto do objeto é o conhecimento das suas múltiplas determinações - tanto mais se reproduzem as determinações de um objeto, tanto mais o pensamento reproduz a sua riqueza (concreção) real. As 'determinações as mais simples' estão postas no nível da universalidade; na imediaticidade do real, elas mostram-se como singularidades - mas o conhecimento do concreto opera-se envolvendo universalidade, singularidade e particularidade. (NETTO, 2011a, p. 45).

A apropriação da dialética hegeliana não se restringe, como querem alguns, somente às suas obras de juventude. Em O Capital, Karl Marx (2013, p. 380-381) deixa evidente o peso da contribuição de Hegel na sua elaboração: "Aqui, como na ciência da natureza, mostra-se a exatidão da lei, descoberta por Hegel em sua Lógica, de que alterações meramente quantitativas, tendo atingido um determinado ponto, convertem-se em diferenças qualitativas." Neste caso, Marx está tratando da passagem histórica do regime feudal para o regime 
capitalista, mostrando que a mudança na quantidade desembolsada na produção por parte do possuidor de dinheiro ou de mercadorias o transforma futuramente em capitalista, alterando a estrutura social numa interação entre mudanças quantitativas e qualitativas. Percebe-se aí que Marx considera as categorias da Lógica de Hegel enquanto elementos centrais para a apreensão do movimento da realidade. Desse modo, acreditamos que toda a pesquisa e todas as conclusões sobre a contribuição marxiana precisam considerar esse movimento dialético que é extraído e expressado no conjunto da sua obra.

Nos processos históricos de revolução social o autor também demonstra que opera a contradição entre o desenvolvimento das forças produtivas e as relações sociais de produção: "As corporações de ofício da Idade Média procuraram impedir pela força a transformação do mestre-artesão em capitalista, limitando [...] o número de trabalhadores que um mestre individual podia empregar." (MARX, 2013, p. 380). Esse tipo de contradição que impulsiona uma futura ruptura com os modos de produção vigentes é sintetizado por Marx em seu Prefácio à contribuição à crítica da economia política.

Ao chegar a uma determinada fase de desenvolvimento, as forças produtivas materiais da sociedade se chocam com as relações de produção existentes, ou, o que não é senão a sua expressão jurídica, com as relações de propriedade dentro das quais se desenvolveram até ali. De formas de desenvolvimento das forças produtivas, estas relações se convertem em obstáculos a elas. E se abre, assim, uma época de revolução social. Ao mudar a base econômica, revoluciona-se, mais ou menos rapidamente, toda a imensa superestrutura erigida sobre ela. (MARX, [1977], p. 301-302, grifos nossos).

Aqui aparece o elemento jurídico enquanto expressão das relações sociais, normatizador de uma determinada forma de organização social que se relaciona e é determinada pelo modo de produção vigente. Diferente das concepções contratualistas que naturalizam e eternizam o status quo com base numa suposta natureza humana $^{3}$, as leis aqui aparecem em seu movimento transitório e histórico, podendo se transformar conjuntamente com a mudança da base econômica. Tal mudança é impulsionada a partir do momento em que as relações sociais de produção já não são compatíveis com o desenvolvimento das forças produtivas.

Seria razoável imaginar que Marx considerava a operacionalização e a resolução deste tipo de contradição histórica como algo que ocorre independente da ação consciente dos indivíduos, grupos, classes e frações de classe sociais? Se, para Marx (2011, p. 25, grifos nossos), os "homens fazem a sua própria história; contudo, não a fazem de livre e espontânea vontade, pois não são eles quem escolhem as circunstâncias sob as quais ela é feita, mas estas lhes foram transmitidas assim como se encontram", o fato de serem ressaltadas aqui as condições objetivas legadas pela história não nega que, apesar delas, os seres humanos fazem sim a sua história.

Qual é uma das principais críticas de Marx a Feuerbach? Justamente o fato de que o seu materialismo apreende a realidade e o sensivel somente "sob a forma do objeto [objekt] ou da contemplação, mas não como atividade humana sensivel, como prática; não subjetivamente.” (MARX; ENGELS, 2007, p. 533, grifos dos autores). A subjetividade e o papel dos sujeitos e das coletividades humanas na história são centrais no pensamento marxiano, que entende que as ideias e as formas de consciência não podem ser descoladas dos seres pensantes, pois estão sempre em interação com sua base prática, com a atividade real da humanidade diante dos conflitos sociais. A conclusão de Marx nunca foi aquela do materialismo vulgar que desconsidera o elemento subjetivo e a historicidade, mas sim a da unidade (na diferença) da consciência e do ser social.

Em termos mais abrangentes, essa mesma interação objetividade-subjetividade coexiste na totalidade social enquanto relação recíproca entre estrutura e superestrutura. As formas ideológicas compõem a superestrutura e perpassam o direito, a política, a religião, a arte e a cultura, relacionando-se com a produção e a reprodução da vida material. O debate do Estado em Marx vincula-se com as formas ideológicas e só pode ser apreendido considerando seu método que expressa o movimento contraditório e reciprocamente determinante das categorias enquanto determinações da existência. Não há como compreender as categorias de maneira fragmentada e isolada: a ideologia se expressa, por exemplo, em nível singular na cotidianidade e também no conjunto da superestrutura, perpassando as relações Estado e sociedade civil.

Georg Lukács (2013, p. 465) considerava que "toda reação humana ao seu meio ambiente socioeconômico, sob certas circunstâncias, pode se tornar ideologia"; tal possibilidade vai depender da função que esta desempenhará no processo dos conflitos sociais. Quando tratamos de sociedades em que o antagonismo de classes está presente, é importante diferenciar o caráter das ideologias que operam a serviço dos interesses da classe dominante do caráter daquelas que se efetivam em favor da luta das classes dominadas. As ideologias que servem aos interesses dominantes precisam preservar o status quo, apresentando os interesses particulares da classe dominante como se fossem universais, além de naturalizar, justificar e eternizar a ordem vigente, sendo, portanto, mistificadoras do real. Já as ideologias que se vinculam com a luta das classes exploradas ou oprimi- 
das têm interesse em desvendar e levar às últimas consequências as contradições do presente, revelando o caráter histórico e transitório da ordem instituída para, assim, projetar a sua superação. A ideologia é:

[...] um meio de luta social, que caracteriza toda sociedade, pelo menos as da 'pré-história' da humanidade. É nessas lutas que tem origem também o significado pejorativo da ideologia, que historicamente se tornou tão importante. A incompatibilidade factual das ideologias em conflito entre si assume as formas mais díspares no curso da história, podendo se manifestar como interpretações de tradições, de convicções religiosas, de teorias e métodos científicos etc., que, no entanto, constituem sempre antes de tudo meios de luta; a questão a ser decidida por eles sempre será um 'o que fazer?' social, e decisivo para a sua confrontação fática é o conteúdo social do 'o que fazer?'; os meios da fundamentação dessa pretensão de condução da práxis social permanecem meios cujo método, cuja constituição etc. sempre depende do hic et nuc social do tipo de luta, do tipo de 'o que fazer?' contido nele. (LUKÁCS, 2013, p. 465-466).

A compreensão marxiana das formas ideológicas perpassa essa interação unitária entre as ideias e os seres sociais pensantes e ativos na realidade concreta, relacionando e ao mesmo tempo diferenciando as mudanças econômico-estruturais das formas "jurídicas, políticas, religiosas, artísticas ou filosóficas, numa palavra, as formas ideológicas em que os homens adquirem consciência desse conflito e lutam para resolvê-lo." (MARX, [1977], p. 301-302, grifos nossos). Essa compreensão, presente na obra de importantes autores do pensamento marxista, entende a ideologia como uma forma de consciência que se materializa nas ações de determinados grupos e/ou classes sociais em conflito nas sociedades humanas. Trata-se de "uma forma de elaboração ideal da realidade que serve para tornar a práxis social dos homens consciente e operativa" (LUKÁCS, 2013, p. 465), sendo que "somente depois de se tornar veículo teórico ou prático para combater conflitos sociais, quaisquer que sejam, grandes ou pequenos, episódicos ou decisivos para o destino da sociedade, eles são ideologia" (LUKÁCS, 2010, p. 38). A ideologia age enquanto uma concepção do mundo que se manifesta implicitamente "no direito, na atividade econômica, em todas as manifestações de vida individuais e coletivas" (GRAMSCI, 2001, p. 98-99). Embora compreenda também essa questão, tal concepção de ideologia não se resume somente à falsa consciência e nem permeia apenas as ideias dominantes na sociedade, mas trata de todas as formas de consciência que se efetivam na prática das classes e dos grupos em conflito na totalidade social.

Tratando das diferentes maneiras de se empregar o conceito de ideologia, Lukács (2014, p. 54, grifos nossos) sintetiza assim sua posição:

Creio que Gramsci tinha toda razão quando observa a esse respeito que nós, em geral, usamos a palavra ideologia em dois significados inteiramente diferentes. De um lado, trata-se do dado real, elementar para um marxista, de que na sociedade cada homem existe numa determinada situação de classe à qual naturalmente pertence a inteira cultura de seu tempo; não pode haver nenhum conteúdo de consciência que não seja determinado pelo hit et nunc da situação atual. Por outro lado, originam-se desta posição certas deformações, razão pela qual nos habituamos a entender a ideologia também como reação deformada em face da realidade. Creio que devemos manter separadas estas duas coisas quando usamos o termo ideologia; por isso - volto agora à questão ontológica - devemos deduzir disso que o homem é, antes de mais nada, como todo organismo, um ser que responde a seu ambiente. Isto significa que o homem constrói os problemas a serem resolvidos e lhes dá resposta com base na sua realidade. Mas uma consciência pretensamente livre de liames sociais, que trabalha por si mesma, puramente a partir do interior, não existe, e ninguém jamais conseguiu demonstrar sua existência. Creio que os chamados intelectuais desprovidos de vinculações sociais, como também o slogan, hoje na moda, do fim da ideologia, sejam uma pura ficção, que não tem propriamente nada a ver com a efetiva situação dos homens reais na sociedade real.

Porém, Lukács (2013, p. 464) considera que Gramsci - apesar do mérito de ter articulado claramente a ideologia em seu duplo significado - contrasta a superestrutura somente com as representações arbitrárias dos homens singulares. Para o autor húngaro, uma ideia que permanece apenas enquanto produto ou alienação do pensamento de um indivíduo, mesmo com uma difusão social relativamente ampla, não transforma um complexo de ideias diretamente em ideologia. Para que sejam ideologia, as formas de consciência precisam desempenhar a função de, em sua correlação com as grandes contradições materiais de uma época, tomar consciência desses conflitos operando objetivamente no sentido de solucioná-los. Isso não significa que elas operem e/ou se transformem somente em períodos de grandes revoluções econômicas, pois sua determinação se aplica à totalidade da vida e do desenvolvimento social.

Toda a elaboração teórica carrega uma orientação ideológica, e o esclarecimento desta e de suas ligações - mais ou menos ocultas - com os interesses de classe conflitantes na sociedade, é de primordial importância para 
lidarmos com o debate teórico-político sem obscurantismos, misticismos ou subjetivismos. Os interesses conflitantes na sociedade se refletem nas elaborações teóricas e se evidenciam em disputas ideológicas e/ou políticas, ora implícitas, ora explícitas. Descartamos qualquer possibilidade de elaboração científica que se pretenda neutra e desvinculada de interesses políticos e ideológicos. Segundo Mészáros (2012, p. 310, grifos nossos):

Certamente, as restrições estruturais fundamentais, correspondentes às características inerentes das forças em questão, finalmente prevalecem, e cumulativamente até estreitam a margem de ação possível das forças sociais rivais, uma em relação à outra. Não obstante, a escolha inevitável de uma alternativa específica em detrimento a outras carrega um compromisso ideológico igualmente inevitável com determinada posição. Além disso, tal escolha também traz a necessidades de se realinhar à perspectiva geral, em sintonia com o curso de ação objetivamente adotado e implícito na alternativa escolhida, combatendo desse modo não apenas o adversário, mas até as possibilidades rivais que poderiam surgir no mesmo lado da confrontação social fundamental. É por isso que todo grande sistema de pensamento, inclusive a orientação marxiana da crítica social, é simultânea, e 'incorrigivelmente', também uma ideologia.

Na sociedade vigente, a afirmação de um direcionamento ideológico transformador ou revolucionário não significa necessariamente uma necessidade de mistificar a realidade, mesmo que existam prioridades na análise orientada pela finalidade desta alternativa política. A condição de parcialidade imposta pelas circunstâncias históricas de uma sociedade de classes direciona a produção de conhecimento para um dos polos antagônicos que movimentam a contraditoriedade intrínseca ao sistema do capital. Somente em meio a essa polarização, e tomando partido pelas classes trabalhadoras, é possível levar tal conflito a sua superação para efetivamente atingir um estado de coisas em que a universalidade do gênero humano possa transpor os limites da parcialidade atual. A busca por essa restauração do ser genérico que compreende, intervém e transforma o mundo real coloca a necessidade da superação dos particularismos vinculados a concepções de mundo (religiosas, políticas, teóricas, etc.) que eternizam relações estranhadas e impedem a efetivação de um projeto generoso que englobe os reais interesses de preservação e desenvolvimento das potencialidades humanas em nível global.

Consideramos infundada qualquer pretensão de enxergar na obra marxiana um determinismo econômico que automaticamente conduziria os processos sociais históricos independentemente da ação consciente dos indivíduos ${ }^{4}$. A própria ideia de uma economia em que a subjetividade humana (mesmo estranhada) não tenha papel ativo, já não é compatível com o materialismo histórico-dialético de Marx, pois as relações econômicas são sociais e, como vimos, não há ação humana descolada das ideias e ideologias operantes.

As conclusões dualistas que buscam contrapor um determinismo ao outro ${ }^{5}$ sempre acabarão distorcendo essa contraditoriedade que é central no método marxiano. Claro que, como já expomos, a base material/ econômica é determinante em última instância e possui um peso bastante significativo, mas os próprios modos de produção são históricos e transitórios e suas superestruturas jurídico-ideológicas têm seu peso e também são determinantes. Além do mais, a superestrutura expressa os conflitos entre diferentes classes e grupos sociais, não sendo, por isso, unívoca.

Karl Marx (2005), transcendendo criticamente o legado de Hegel, busca se contrapor a uma visão idealizada do Direito e chama a atenção para os limites de se postular abstratamente a razão humana ou a ética no Estado. Embora Hegel considere, à sua maneira, as determinações deste Estado nas diferentes instituições da sociedade civil - diga-se: família, corporações, etc. - ele mantém essas determinantes apenas no plano ideal, pois acredita que suas contradições, em última instância, são resolvidas e universalizadas no Estado moderno enquanto síntese da ética e da racionalidade.

Hegel se contenta com o fato de que, no estado - que ele apresenta como a existência autoconsciente do espírito ético - esse espírito ético seja o determinante apenas em si, segundo a ideia universal. Ele não deixa que a sociedade se torne o determinante real, pois para isso é necessário um sujeito real e ele possui apenas um sujeito abstrato, uma imaginação. (MARX, 2005, p. 136, grifos do autor).

Marx quer trazer a sociedade civil na sua concretude, nos seus conflitos e lutas de classes, e enfatiza com necessário realismo o peso que a propriedade privada e a classe economicamente dominante possuem sob as instituições. O Estado é, portanto, determinado pelos conflitos e pela hegemonia existente na sociedade civil. Ele não é a forma autoconsciente de uma ética em geral, mas expressa a ética da classe economicamente dominante. Não constitui uma racionalidade universal, mas a racionalidade da classe dominante. O caráter do Estado na sociedade burguesa segue sendo, deste modo, transitório e histórico, e não, como em Hegel, o ponto de chegada do movimento do espírito em busca de sua síntese ética e racional. 
István Mészáros (2015, p. 74) considera que é mérito de Hegel ter tentado sintetizar o fenecimento da antiga ordem feudal e o florescimento da sociedade burguesa com suas novas contradições a partir da concepção de relação entre a sociedade civil e o Estado ético. Mas a crença de que essa síntese iria subsumir os conflitos capitalistas sob a "estrutura geral permanente do Estado idealizado" que estaria "destinado a reconciliar as contradições da sociedade civil" é o que marca os limites históricos da sua abordagem. Hegel acreditava em um encerramento histórico advindo da sociedade moderna e seu Estado ético" (MÉSZÁROS, 2015, p. 74, grifos do autor), expressando um horizonte de classe que não era capaz de projetar para além dos limites da sociedade burguesa.

No Prefácio, Marx sintetiza seu acerto de contas com Hegel e expõe sua concepção de Estado e de sociedade civil:

O meu primeiro trabalho, empreendido para resolver as dúvidas que me assaltavam, foi uma revisão crítica da filosofia hegeliana do direito, trabalho cuja introdução veio a lume em 1844, nos Anais Franco-Alemães, que se publicavam em Paris. A minha investigação desembocava no resultado de que tanto as relações jurídicas como as formas de Estado não podem ser compreendidas por si mesmas nem pela chamada evolução geral do espírito humano, mas se baseiam, pelo contrário, nas condições materiais de vida cujo conjunto Hegel resume, seguindo o precedente dos ingleses e franceses do século XVIII, sob o nome de 'sociedade civil', e que a anatomia da sociedade civil precisa ser procurada na economia política. (MARX, [1977], p. 301-302).

Além de sua posição materialista fundamental, em que as condições materiais de vida são a base para compreender as relações jurídicas e as formas de Estado, ressaltamos aqui a compreensão da anatomia da sociedade civil a partir da economia política. A sociedade civil, que tem o Estado como expressão da sua correlação de forças, não é uma coleção abstrata de instituições autônomas ao Estado, mas sim a base real das condições materiais de vida, da produção e reprodução da vida social, de uma estrutura socioeconômica permeada por relações de exploração/dominação e pelos conflitos entre classes e grupos sociais.

Numa sociedade baseada na exploração de uma classe por outra, o peso da influência que a classe economicamente dominante detém na sociedade civil e no Estado será continuamente predominante, podendo deixar de ser majoritário somente em curtos períodos de alto acirramento da luta de classes ou em um processo de revolução social que destitua materialmente o poder da classe dominante na estrutura socioeconômica. Isso não nega a existência permanente de disputas que resultam em concessões e/ou conquistas por parte das classes em luta.

Marx e Engels (2008, p. 12) no generoso panfleto conhecido como Manifesto Comunista, afirmam que o "poder do Estado moderno não passa de um comitê que administra os negócios comuns da classe burguesa como um todo." Em termos estritamente científicos, descartando a estética de panfleto político que é própria da obra em questão, podemos sim considerar generalista demais afirmar que o Estado não passa disso, embora majoritariamente ele tenha de fato esse caráter. Porém, algumas páginas adiante os autores tratam do desenvolvimento do proletariado que ocorre concomitantemente ao desenvolvimento da burguesia, sendo a luta entre essas duas principais classes antagônicas uma contradição central na existência do capitalismo. O proletariado eleva seu nível de consciência e organização, altera as correlações de força através da luta e obtém conquistas também na esfera do Estado.

Esta organização dos proletários em classe, e com isso em partido político, pode ser destruída em qualquer momento pela concorrência entre os próprios trabalhadores. Porém, ela ressurge sempre, mais vigorosa, mais firme, mais poderosa. Ela força o reconhecimento dos interesses específicos dos trabalhadores na forma de leis, na medida em que eles se aproveitam das divisões entre os burgueses. Assim ocorreu, por exemplo, quando foi aprovada a limitação da jornada de trabalho em dez horas na Inglaterra. (MARX; ENGELS, 2008, p. 24, grifos nossos).

Esta luta permanente que altera constantemente as correlações de força deve ser considerada no âmbito da totalidade social, das alterações quantitativas e qualitativas, das interações entre universalidade, singularidade e particularidade, de seu movimento constantemente contraditório e das mediações entre Estado e sociedade civil. As conquistas de direitos por parte do proletariado, tal como a redução da jornada de trabalho ressaltada por Marx e Engels (2008) no Manifesto, demonstram a centralidade da luta de classes, tanto na determinação do caráter do Estado quanto no próprio movimento da estrutura econômica da sociedade.

Basta lembrar como o mais-valor relativo, cuja constituição interna é bem mais social do que a do mais-valor absoluto, surge como resultado da resistência da classe operária, ou seja, não apenas como fruto da 
dialética imanente à dinâmica interna da economia capitalista, mas como resultado da luta de classes. (LUKÁCS, 2012, p. 349, grifos nossos).

As próprias táticas políticas indicadas pelo Manifesto comunista em meados do século retrasado, tais como: a aliança com o partido democrata-socialista na França e o apoio aos radicais na Suíça, são posições que, em nossa avaliação, consideram essa possibilidade de disputar também a institucionalidade e acumular forças para uma conjuntura mais favorável ao avanço da luta do proletariado.

Portanto, defendemos a posição de que não há em Marx um determinismo econômico e nem uma visão simplista de Estado que desconsidere a possibilidade da disputa de seus espaços institucionais. Não é possível separar completamente as disputas no âmbito econômico ou da sociedade civil, das disputas no conjunto da superestrutura ou no Estado, pois ambas sempre se relacionam e uma expressa a outra, mesmo que nem sempre essa expressão tenha uma evidência mais acentuada. Tal compreensão não significa considerar que somente as obras de Marx dão conta desta problemática, até porque o autor não logrou em vida aprofundar o seu estudo do Estado moderno e temos valiosas contribuições que desenvolveram este tema ao longo dos séculos XX e XXI.

\section{Apontamentos sobre o Estado na contemporaneidade}

Conforme o caráter burguês do Estado se desenvolve, ele cria novas concepções acerca "do Direito, Política, Economia, Educação e, consequentemente, de Ética, estabelecendo uma unidade não apenas no plano jurídico-formal, mas ideologicamente projetada para toda a sociedade" (SIMIONATTO, 2009, p. 42). Esta projeção que se espraia por todos os âmbitos da existência, demonstra que a disputa ideológica acerca das concepções de mundo está dada em cada espaço da produção e da reprodução social, não sendo coerente e nem estratégico dispensar tal disputa em nenhum espaço que expresse no seu interior as polarizações colocadas na sociedade em geral. Na contemporaneidade cabe o desafio de desvendar as particularidades da superestrutura na fase monopolista do capitalismo, que traz consigo uma maior complexidade das instituições jurídicas e ideológicas da sociedade.

Para Netto (2011b, p. 24-25, grifos do autor) o Estado burguês que na fase ascendente do capitalismo "atuara como ocioso guardião das condições externas da produção capitalista", extrapolando o seu papel de garantidor da propriedade privada dos meios de produção burgueses somente em momentos precisos que demandavam "um intervencionismo emergencial, episódico, pontual", na era atual (a dos monopólios) complexifica e intensifica sua intervenção nas esferas econômica, social e política da sociedade, tendo como eixo central de sua intervenção uma direção no sentido de "garantir os superlucros dos monopólios" desempenhando para isso "uma multiplicidade de funções". O Estado foi "capturado pela lógica do capital monopolista" no sentido de que é hegemonicamente controlado pelos grandes monopólios numa tendência de "integração orgânica entre os aparatos privados dos monopólios e as instituições estatais" (NETTO, 2011b, p. 24-25).

A simbiose entre poder burguês e Estado pode ser verificada no "sempre crescente envolvimento direto e indireto do Estado em salvaguardar a continuidade do modo de produção do metabolismo social do capital." (MÉSZÁROS, 2003 , p. 29), numa série de ações do poder público para garantir e legitimar a sua expansão. Desse modo, "afirmase a centralidade do Estado, peça-chave da expansão global

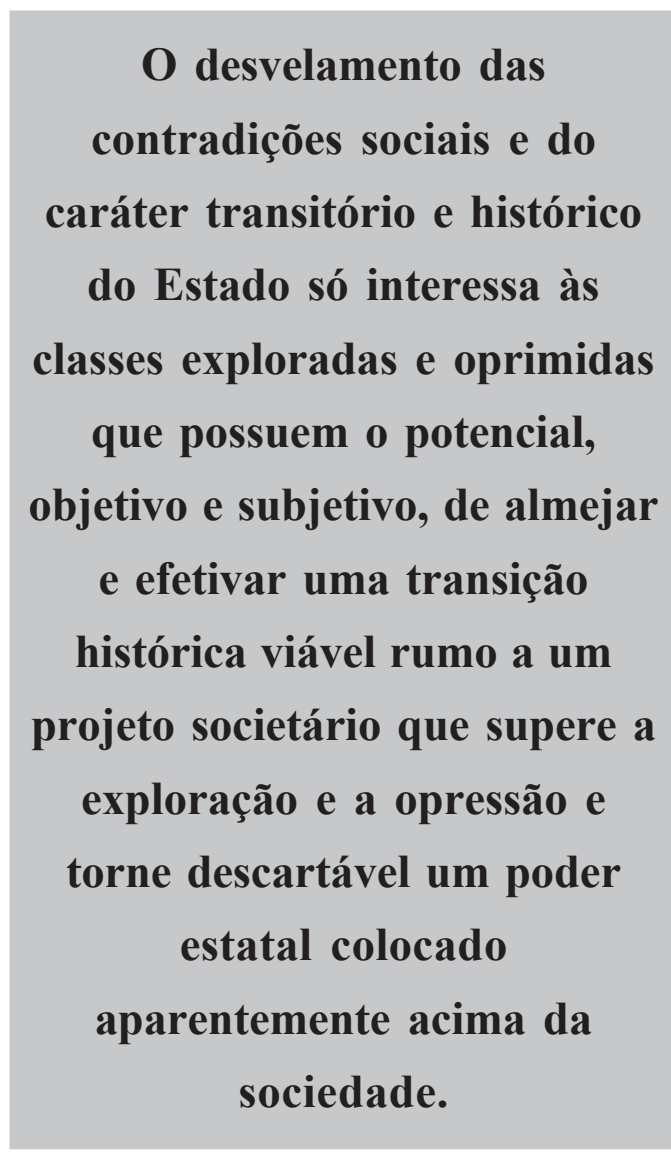
das empresas multinacionais", ele "interfere na gestão da crise e na competição intercapitalista" e, embora os mercados transcendam os Estados, eles "operam nas suas fronteiras" (IAMAMOTO, 2008, p. 122). Ao contrário do desejo dos que acreditam na livre iniciativa e na não intervenção do Estado como soluções para 
o progresso no interior da ordem capitalista, a concentração cada vez maior dos monopólios e a intervenção do Estado a serviço dos mesmos são tendências intrínsecas à própria lógica da acumulação capitalista.

De acordo com Lara (2011, p. 26, grifos do autor):

Para assegurar os mecanismos tencionados pela ordem monopólica, o Estado é reivindicado como mecanismo de intervenção extraeconômica, cuja função é assegurar os grandes lucros dos monopólios e desempenhar funções econômicas como investimentos em setores menos rentáveis e em empresas com dificuldade de crescimento ou em crise; entregar aos monopólios os complexos construídos com fundos públicos, além de outros fatores que os fortalecem em detrimento dos custeios do Estado. O Estado passa a ter como principal objetivo garantir as condições necessárias à acumulação e valorização do capital monopolista.

O Estado também precisa se legitimar politicamente perante a sociedade como um todo e faz isso "incorporando outros protagonistas sócio-políticos", alargando, assim, a "sua base de sustentação e legitimação sócio-política", através da "generalização e a institucionalização de direitos e garantias cívicas e sociais", permitindo-lhe "organizar um consenso que assegura o seu desempenho" (NETTO, 2011b, p. 27). Essa "maneira de agir do Estado reveste-se de um grande poder desmobilizador, na medida em que bloqueia as iniciativas da sociedade civil na articulação de interesses e propostas voltados à luta pela superação entre 'governantes e governados', dirigentes e dirigidos." (SIMIONATTO, 2009, p. 42). Esse bloqueio, no entanto, não impede que a luta de classes siga impulsionando novos movimentos que tencionam a ordem social visando à conquista pontual de direitos ou a superação dos limites estruturais vigentes.

Fernandes (2005, p. 424) trata do processo desmobilizador por parte do Estado utilizando a categoria "democracia de cooptação", afirmando que a mesma possui "pouca eficácia e pouca 'flexibilidade' em nações capitalistas pobres onde a extrema concentração da riqueza e do poder" deixa para as classes dominantes "um escasso excedente para dividir na compra de alianças ou de lealdades." Daí a importância de não se desprezar as particularidades existentes nos diferentes países e regiões do globo onde a consolidação do modo de produção capitalista, embora possua elementos estruturais universais, também traz especificidades de seu desenvolvimento desigual que precisam ser consideradas para pensar as diferentes formas do Estado burguês na contemporaneidade. O nível da flexibilidade e do potencial das disputas que almejam conquistas no âmbito estatal pode variar de acordo com o tipo de poder burguês cristalizado nos diferentes processos históricos de revolução burguesa.

No jogo democrático o Estado capturado pelo capitalismo monopolista "é permeável a demandas das classes subalternas, que podem fazer incidir nele seus interesses e suas reivindicações imediatas", na medida em que "este processo é todo ele tensionado, não só pelas exigências da ordem monopólica, mas pelos conflitos que esta faz dimanar em toda a escala societária" (NETTO, 2011b, p. 29, grifos nossos). Em outras palavras, não há como considerar unilateral o sentido das concessões e conquistas respaldadas pelo Estado burguês, o caráter das mesmas e sua efetividade estão em disputa pelas classes em luta e a implementação dos direitos formais depende da pressão e da correlação de forças colocada.

\section{Considerações finais}

Com as aproximações e questões aqui levantadas concluímos que a concepção marxiana de Estado possui plena validade como ponto de partida para o desenvolvimento do estudo das metamorfoses do Estado moderno e contemporâneo. $\mathrm{O}$ método histórico-dialético, se levado a cabo em seu verdadeiro caráter, não permite conclusões dogmáticas ou esquemáticas, constituindo uma ferramenta fundamental para a permanente atualização de nossas análises sobre a sociedade burguesa em toda sua complexidade.

A relação entre Estado e sociedade civil tem por base a estrutura econômica da sociedade, sendo que a luta de classes é um motor deste processo em que a subjetividade humana interage permanentemente nas disputas sócio-políticas que decorrem dos conflitos sociais. Embora o poder da classe dominante seja majoritário, a correlação de forças na sociedade civil e no Estado está sempre em disputa e pode ser tensionada pela pressão das classes exploradas e oprimidas.

$\mathrm{Na}$ era contemporânea em que o capitalismo atinge seu estágio monopolista há uma simbiose entre o capital monopolista e o Estado, decorrente da necessidade de assegurar o domínio e a expansão econômica dos monopólios. Neste contexto, o Estado e toda superestrutura se complexificam em sua busca permanente pelo consenso, trazendo maior centralidade para as disputas ideológicas nos âmbitos educacionais, políticos, jurídicos, artísticos, midiáticos, etc., não sendo possível desprezar a luta política em nenhuma das instituições que permeiam esses conflitos, desde que essa atuação se articule com um projeto que almeje a mudança na totalidade das relações socioeconômicas vigentes. 
Para que essa mudança global ocorra tornam-se necessários instrumentos políticos que superem a particularidade e o corporativismo de determinada categoria ou setor social, conformando uma aliança abrangente e capaz de se constituir enquanto um bloco contra hegemônico. O processo de consolidação dessa aliança pode ser traduzido como a formação do bloco histórico, no qual há uma estrutura social - as classes e grupos sociais - que depende diretamente das relações entre as forças produtivas; mas também há uma superestrutura ideológica e política. Tal afirmação, segundo Gramsci (2001, p. 238),

Conduz ao fortalecimento da concepção de 'bloco histórico', no qual, precisamente as forças materiais são o conteúdo e as ideologias são a forma, distinção entre forma e conteúdo puramente didática, já que as forças materiais não seriam historicamente concebíveis sem forma e as ideologias seriam fantasias individuais sem as forças materiais.

Essa intencionalidade revolucionária é intrínseca à formulação de Estado aqui apresentada. O desvelamento das contradições sociais e do caráter transitório e histórico do Estado só interessa às classes exploradas e oprimidas que possuem o potencial, objetivo e subjetivo, de almejar e efetivar uma transição histórica viável rumo a um projeto societário que supere a exploração e a opressão e torne descartável um poder estatal colocado aparentemente acima da sociedade.

\section{Referências}

FERNANDES, F. A revolução burguesa no Brasil: ensaio de interpretação sociológica. 5. ed. São Paulo: Globo, 2005.

GRAMSCI, A. Cadernos do cárcere. Volume 1: Introdução ao estudo da filosofia. A filosofia de Benedetto Croce. 2. ed. Rio de Janeiro: Civilização Brasileira, 2001.

HOBBES, T. Leviatã ou matéria, forma e poder de um estado eclesiástico e civil. São Paulo: Abril, 1978. (Col. Os pensadores).

IAMAMOTO, M. V. Serviço Social em tempo de capital fetiche: capital financeiro, trabalho e questão social. Porto Alegre: Cortez Editora, 2008.

LARA, R. Produção de conhecimento no Serviço Social: o mundo do trabalho em debate. São Paulo: UNESP, 2011.

LUKÁCS, G. Conversando com Lukács. São Paulo: Instituto Lukács, 2014.

. Para uma ontologia do ser social. São Paulo: Boitempo, 2012.

. Para uma ontologia do ser social II. São Paulo: Boitempo, 2013.

Prolegômenos para uma ontologia do ser social. São Paulo: Boitempo, 2010.

MARX, K. O 18 de Brumário de Luís Bonaparte. São Paulo: Boitempo, 2011.

O Capital: crítica da economia política: Livro I: o processo de produção do capital. São Paulo: Boitempo, 2013.

. Contribuição para a crítica da econômica política. São Paulo: Expressão Popular, 2008.

. Crítica da filosofia do direito de Hegel. São Paulo: Boitempo, 2005.

Prefácio à Contribuição à Crítica da Economia Política. In: MARX, Karl; ENGELS, Friedrich Karl Marx e Friedrich Engels -

Textos 3. São Paulo: Edições Sociais, [1977]. p. 300-303. (Originalmente publicado em alemão, em 1859).

.; ENGELS, F. A ideologia alemã. São Paulo: Boitempo, 2007.

. Manifesto do partido comunista. São Paulo: Expressão Popular, 2008.

MÉSZÁROS, I. A montanha que devemos conquistar. São Paulo: Boitempo, 2015.

O poder da ideologia. São Paulo: Boitempo, 2012.

O Século XXI: Socialismo ou Barbárie. São Paulo: Boitempo, 2003.

NETTO, J. P. Introdução ao estudo do método de Marx. São Paulo: Expressão Popular, 2011a.

Capitalismo monopolista e serviço social. São Paulo: Cortez, 2011 b.

SIMIONATTO, I. Classes subalternas, lutas de classe e hegemonia: uma abordagem gramsciana. Revista Katálysis, Florianópolis, v. 12 , n. 1, p. 41-49, jan./jun. 2009.

\section{Notas}

1 Por obra marxiana consideramos o conjunto das elaborações de Karl Marx, incluindo aquelas feitas em parceria com Friedrich Engels.

2 Na dialética marxiana a "contraditoriedade se apresenta como motor permanente da relação dinâmica entre complexos, entre processos que surgem de tais relações. Portanto, a contraditoriedade não é apenas, como em Hegel, a forma de passagem repentina de um stadium a outro, mas também a força motriz do próprio processo normal.” (LUKÁCS, 2012, p. 291).

3 Em Hobbes (1978), por exemplo, o Estado de natureza seria uma guerra de todos contra todos onde o homem seria o lobo do próprio homem, sendo assim necessário o contrato social que resulta na ordem e no Estado vigente. 
4 “[...] no registro dos manuais, Marx aparece geralmente como um teórico fatorialista-ele teria sido aquele que, na análise da história e da sociedade, situou o ‘fator econômico' como determinante em relação aos 'fatores' sociais, culturais, etc. [...] Engels, em carta de setembro de 1890, já advertia contra essa deformação: recordando que Marx e ele sustentavam tão somente a tese segundo a qual a produção e a reprodução da vida real apenas em última instância determinavam a história" (NETTO, 2011a, p. 14, grifos do autor).

5 Ou seja, supervalorizar, por exemplo, o elemento subjetivo em detrimento do objetivo ou vice-versa.

\section{Davi Machado Perez}

daviperez1987@gmail.com

Mestrado em Serviço Social pelo Programa de Pós-Graduação em Serviço Social da Universidade Federal de Santa Catarina (UFSC)

Professor Substituto no Curso de Serviço Social da Universidade Federal do Tocantins - Campus de Miracema (UFT)

\section{UFT}

Campus de Miracema

Avenida Lourdes Solino $\mathrm{s} / \mathrm{n}^{\circ}$ - Setor Universitário

Miracema - Tocantins - Brasil

CEP: $77.650-000$ 